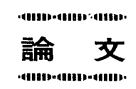

\title{
磨砕したコークスを原料とする 高強度硬質炭素材の試作
}

\author{
小川一太郎*・小林 和 夫 $^{*}$ ・本田 英昌 ${ }^{* *}$
}

\author{
（昭和 52 年 10 月 7 日受理） \\ Preparation of Strong and Hard-Type Carbon Solids \\ from Ground Petroleum Coke Powder \\ Ichitaro Ogawa, Kazuo Kobayashi and Hidemasa Honda \\ National Industrial Research Institute of Kyushu \\ Shuku-machi, Tosu-shi, Saga-ken, Japan
}

\begin{abstract}
Carbon solids were prepared from ground green-petroleum coke powder without using any binder material. Green-petroleum coke powder was ground for various times from $15 \mathrm{~min}$ to $44 \mathrm{hr}$ and was formed into cylindrical shape with diameter of $20 \mathrm{~mm}$ under a pressure of $2000 \mathrm{~kg} / \mathrm{cm}^{2}$. Then the formed samples were heat-treated at $1000^{\circ} \mathrm{C}$ and then to the final temperature at $2700{ }^{\circ} \mathrm{C}$ or $2800^{\circ} \mathrm{C}$.

Some properties of the carbon solid thus obtained were investigated in relation to grinding time. Bulk density increased from $1.55 \mathrm{~g} / \mathrm{cm}^{3}$ for $15 \mathrm{~min}$-ground coke to $1.90 \mathrm{~g} / \mathrm{cm}^{3}$ for $44 \mathrm{hr}$-ground and porosity also decreased from $23 \%$ to about $5 \%$. Shore hardness, compressive strength and $d_{(002)}$ spacing of carbon solids increased with time. The carbon solid with Shore hardness of about 100, compressive strength of $1500 \mathrm{~kg} / \mathrm{cm}^{2}$ and $d_{(002)}$ spacing of $3.39 \AA$ was obtained from the powder ground for $44 \mathrm{hr}$.
\end{abstract}

\section{1. はしがき}

一般に炭素材は, 骨材コークスと粘結材を混練し, こ れを成形焼成することによって製造される。しかし，乙 の方法では, 高密度の炭素材は得られにくく，また，長 期間の工程を必要としている。乙のため, 最近, 炭素材 の新製造法の開発が多数試みられている。その一つとし て，粘結材を使用せずに炭素材を製造する方法があげ られる。たとえば，仮焼コークスを原料としたH．．． (Hot isostatic press) ${ }^{1)}$ や超高圧下加熱 ${ }^{2,3)}$ による高密 度炭素材の製造法, あるいは, 燒結促進剂を添加した原 料粉末を加圧焼成するととによる高密度炭素材の製造 法 $^{4 \sim 6)}$ がある。また，いく分かの揮発分を含む，いわゆ る半成コークス, あるいはそれに類する素材を原料とし

*九州工業技術試験所：佐賀県鳥栖市宿町

**現在, C PC 研究会, 日本産業技術振興協会: 東京 都港区西新橋 2 丁目 7 番地
た常圧下焼成による炭素材の製造法がある。たとえば， 改質ピッチを使用する方法 ${ }^{7}$ 11), メンカーボンマイクロ ビーズを使用する方法 ${ }^{12)}$, 低温乾留ピッチコークスを使 用する方法 ${ }^{13)}$ 等が試みられている。

一方, 粉体の性質に与える磨砕の影響については, メ カノケミストリーとして広範囲の研究がなされている。 その中で粉体の焼結に関するものでは, その成形性, お よび焼結性が原料の磨砕あるいは粉砕により向上する例 が知られている ${ }^{14)}$ 。炭素類においても磨砕に関して多く の研究が行われているが, 炭素類の焼結性に与える原料 粉末の磨砕の効果を調べた例はみあたらない。

そこで筆者らは試料として約 $500^{\circ} \mathrm{C}$ で製造されたコー クス（生コークス）を選び, 乙れを長時間磨砕した後, 成 形後, 高温処理することにより, 炭素焼成体の製造を試 みた。本報告では, 磨砕によもなう原料コークスの性状 変化, および得られた焼成体の 2,3 の物性について述べ る。 


\section{2. 実験方法}

1) 焼成体原料の調整上予備成形

実験に供した原料はディレードコーカー法により，約 $500^{\circ} \mathrm{C}$ の温度で製造さ扎た石油コークス(生コークス)で, その性状は揮発分量 $8.7 \%$ ，みかけ比重 $1.35 \mathrm{~g} / \mathrm{cm}^{3}$ であ る。この原料粉末（60〜100メッシュ）在らい加機によ り空気中で 15 分〜 44 時間磨砕した。らいかい機の乳鉢 上乳棒は炭化タングステン製，乳鉢の寸法は深さ $65 \mathrm{~mm}$, 内径 $140 \mathrm{~mm}$, 乳棒の回転速度は自転 165 , 公転 $50 \mathrm{rpm}$

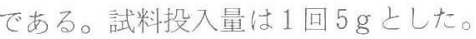

次に, 所定時間摩砕した原料は, 内径 $20 \mathrm{~mm}$ 片押し ダイスを用いて万能試験機により予備加圧成形した。 1 回の成形量は $5 \mathrm{~g}$, 成形死は $2000 \mathrm{~kg} / \mathrm{cm}^{2}$ 亡した。

2) 焼 成

次に，予備成形に上り得られた成形体（約 $20 \mathrm{~mm} \phi \times$ $12 \mathrm{~mm}$ ) 在炭素粉末中に埋め込み, 窒素父流中 $1000{ }^{\circ} \mathrm{C}$ で 1 時間焼成した後, さらにタンマン炉在用いて,アルゴ ン気流中 $2800^{\circ} \mathrm{C}$ ，または $2700^{\circ} \mathrm{C}$ で 60 分および 90 分焼 成した。昇温速度は $1000^{\circ} \mathrm{C}$ まで通常 $300^{\circ} \mathrm{C} / \mathrm{hr}, 1000^{\circ} \mathrm{C}$ 以上では $400^{\circ} \mathrm{C} / \mathrm{hr}$ とした。また， $1000^{\circ} \mathrm{C}$ までの焼成で は昇温速度を $25 \sim 400^{\circ} \mathrm{C} / \mathrm{hr}$ の範囲で变化させて, 得ら れる焼成体の形状に与える昇温速度の影響を調べた。

3）物性测定

各所定侍間磨砕した原料粉木についてはそれぞれ，揮 発分量, みか子比重, 拉よび $(002) X$ 線回折四形の变化 を調へた。また。磨硚時間に上もなう粉末形状の変化を 走查型電子顕微鏡により観察した。

$1000^{\circ} \mathrm{C}$ 焼成体については, 焼成による重量減少率, 線 収縮率および気孔率の変化老測定し, 焼成体の緻密さに 与える原料粉末磨砕時間の影響を調べた。

$2700^{\circ} \mathrm{C}, 2800^{\circ} \mathrm{C}$ 焼成体については, 汃さ密度, 压縮 強度, ショアー硬度, および試料研磨面の走査型電子顕
微鏡観察を行った。また， X線回折法により $d_{(002)}$ と $a_{0}$ の值老求め, 焼成体の黒鉛化度亡原料粉末磨砕時間上の 関係を調べた 測定法は以下の上抢り行った。

揮発分量：JIS. M8812 亿従った

加さ密度：マイクロメータにより, 寸法かさ密度と して求めた。

みかけ比重：ピクノメータを使用して, ブタノール浸 液比重として求めた。

圧 縮強度：端面在研削して平滑にした試料在武験片

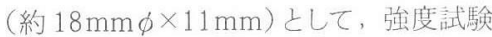
機により歪速度 $0.5 \mathrm{~mm} / \mathrm{m}$ inで行った。

気孔率：武料起水中で約 3 時間煮沸して放泠し， 水中重量亡飽水重量により求めた。

$\mathrm{X}$ 線回 折：自動記録式X線回折装置により，学振法 に準じて測定した。

\section{3. 実験結果}

1）磨砕によもなう原料粉末の性状变化

磨砕時間に上屯なう原料粉末の走榃型電子顕微鏡写真 の例在Fig. 1 亿示す。磨砕処理前の原料粉末は60〜100 メッシュに粒度調整したものであり，従って150〜250 ルmの粒径在有している。この原料粉木は15 分間の磨砕 により, Fig. 1(a)に示すように数 $\mu \mathrm{m}$ 数十 $\mu \mathrm{m} の$ 粒径 分布在むつ粉末となる。個々の粒子は縁が角ばった不規 則な形態を示し，との段階では磨砕により単にコークス 粒子が破壊され，細かな破片椟になったにすぎないとと を示している。磨砕時間が長くなるにつれて Fig.1(b) (6 時間磨砕)に示すように, 粒子径は減少し, かつ比較 的均一化してくる。また，粒子形状がやや丸みを带びて くるのが観察される。この粒子の球状化はFig. 1(c)(44 時間磨砕)に示すように, 磨砕㭙間が長くなる程顕著に なる傾向がある。しかし, 粒径の減少はあはや進行せず, 1〜 $5 \mu \mathrm{m}$ の粒径圭保っているのが特徽的である。また，
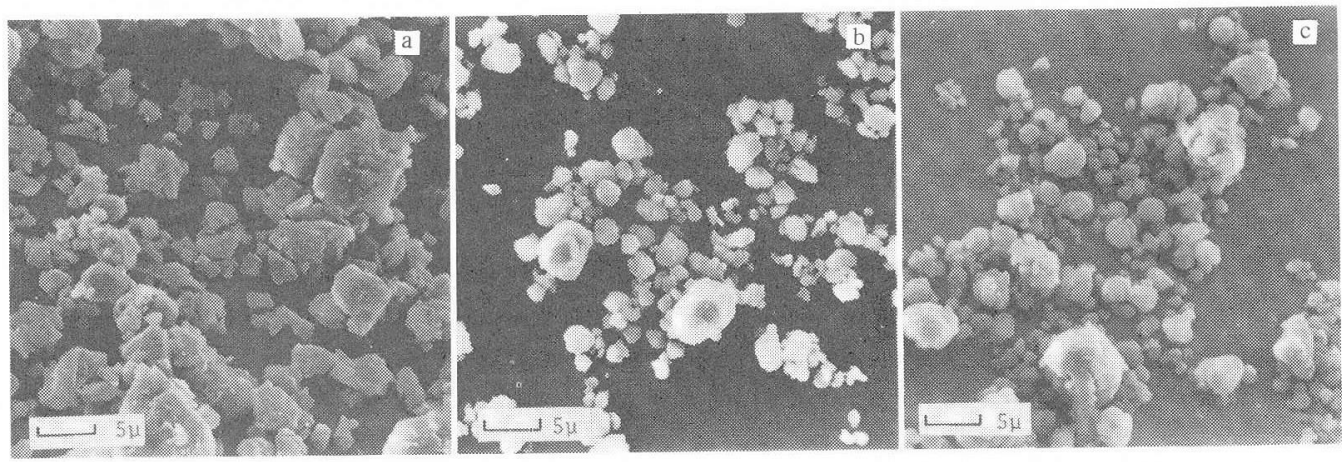

Fig. 1 Scanning electron micrographs of green petroleum coke powders.
a) Ground for $15 \mathrm{~min}$
b) Ground for $6 \mathrm{hr}$
c) Ground for $44 \mathrm{hr}$ 
粒子表面にはいくつかのクラックが酤察さ机る。

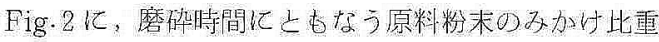

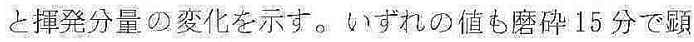

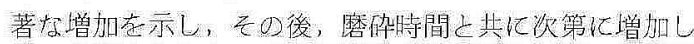
ていく㑯向表している。

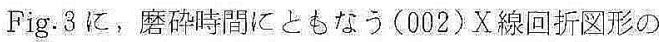

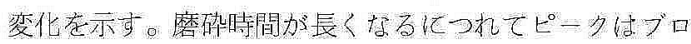

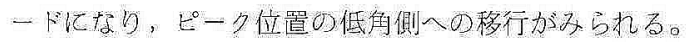

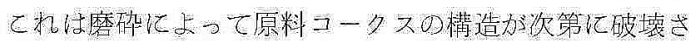
机，より無定形化していくとと走している。

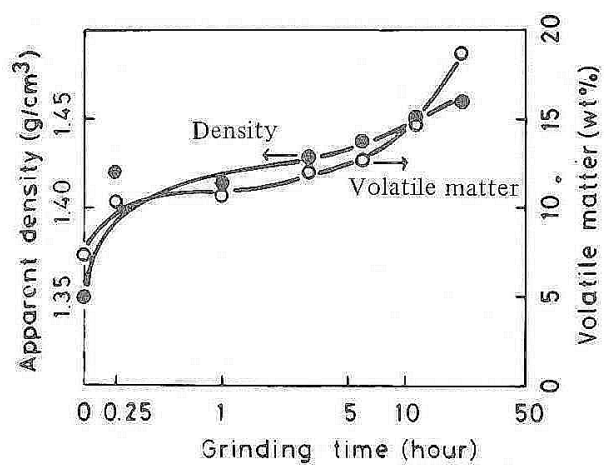

Fig. 2 Changes of immersion density and volatile matter of the powder with grinding time.

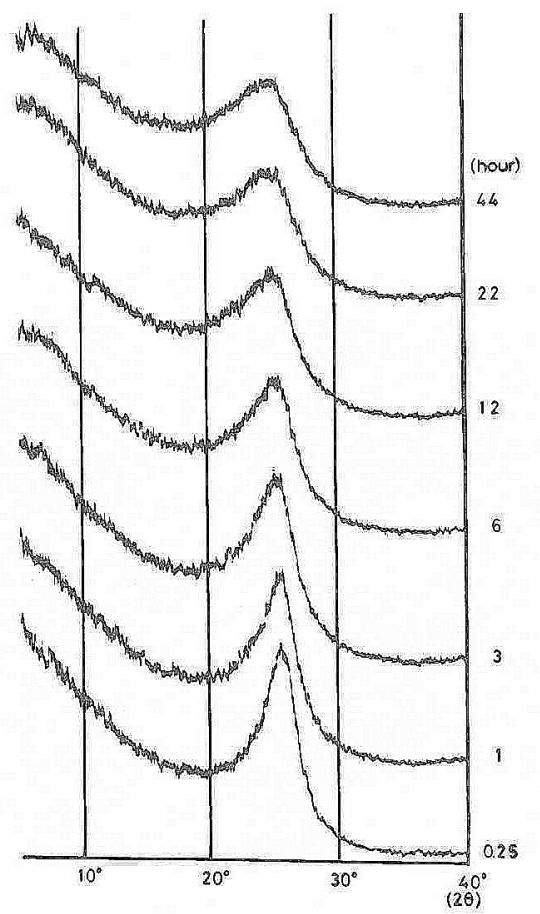

Fig. 3 Diffraction profiles of the powders ground for various times.

\section{2) 烧成体の性状}

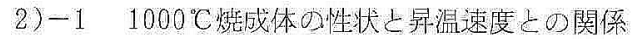
磨础処理した原料粉末心いずれも10\%前後の揮登方走

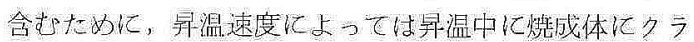

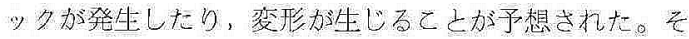

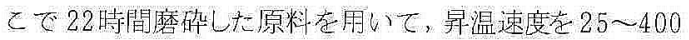

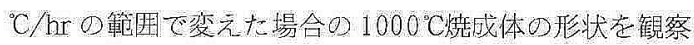

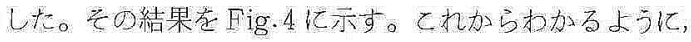

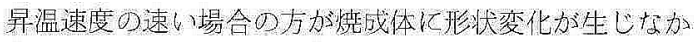

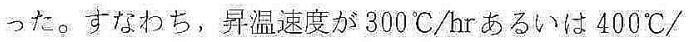
hr の場合には变形やクラック的発生したしが， $1000^{\circ} \mathrm{C}$ hr の場合には数本のクラックか発生し, さらに $25^{\circ} \mathrm{C} / \mathrm{hr}$

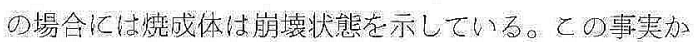

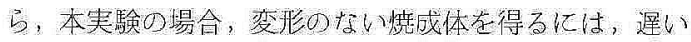
昇温速度上り 6 比

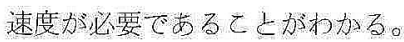

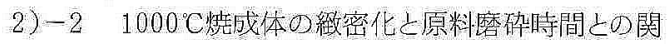 椂}

$300^{\circ} \mathrm{C} /$ h D昇温速度により得られた $1000^{\circ} \mathrm{C}$ 暁成体の

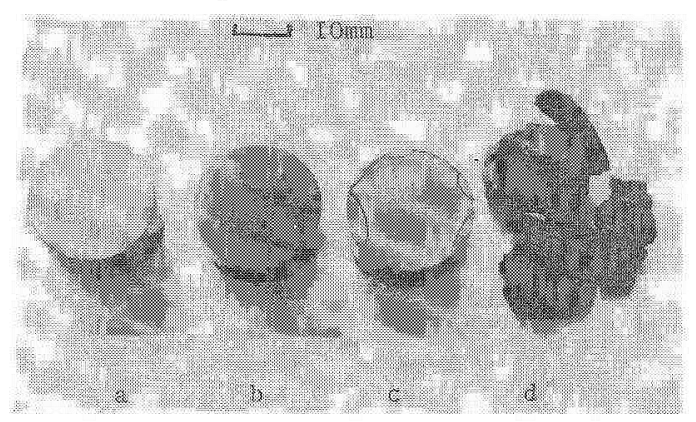

Fig. 4 Appearance of carbon solid made from the $22 \mathrm{hr}$-ground powder at $1000^{\circ} \mathrm{C}$ with various heating rates.
a: $400^{\circ} \mathrm{C} / \mathrm{hr}$
b: $300^{\circ} \mathrm{C} / \mathrm{hr}$
c. $100^{\circ} \mathrm{C} / \mathrm{hr}$
d: $25^{\circ} \mathrm{C} / \mathrm{hr}$

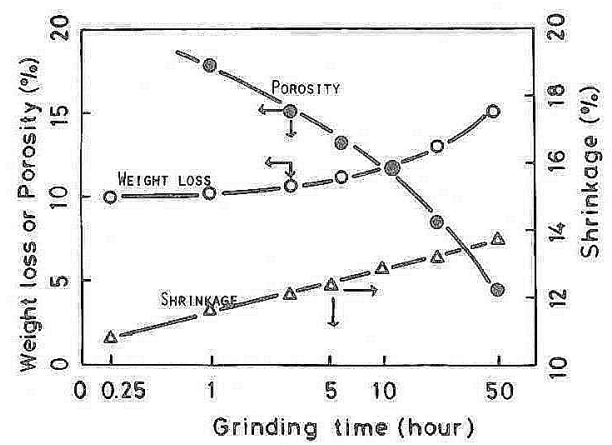

Fig. 5 Changes of weight loss, porosity and shrinkage of carbon solids heat-treated at $1000^{\circ} \mathrm{C}$ with grinding time. 
線仪縮率，重量隇少流求よび気孔率々原料磨砕時間しの 関係老Fig. 5 に示す。図加らわ加るよう飞，重量減少率

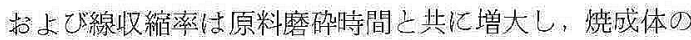
気孔率は減少する。重量隇少率の増大は，Fig.2に示し たように原料の揮発分为磨碎洔間上共に多くなることに よるものである。線收縮率の璔大已気孔率の減少は，原 料磨碚時間が長い荠成体はど，維密化がより著しいとと 起ている。

\section{2) $-32700^{\circ} \mathrm{C}, 2800^{\circ} \mathrm{C}$ 邺成体の物性と原料磨砕時} 間とD関係

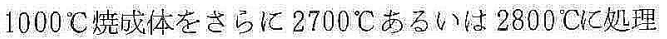
した焼成体の己，3の物性と原料磨砕時間上の関係を述一 る。

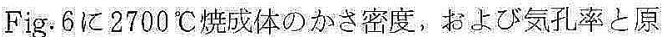
料磨砕時間との関係老示す。焼成体の加さ密度は，原料 磨砕時間の長いものはど大きく、気孔率将小さい。特に 44 時間磨砕では 1.92 の高い加さ密度を示す。

Fig. 7 亿 2700 C绫成体の圧縮強度执よびショア一硬度

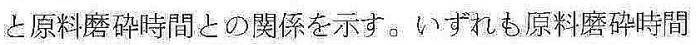

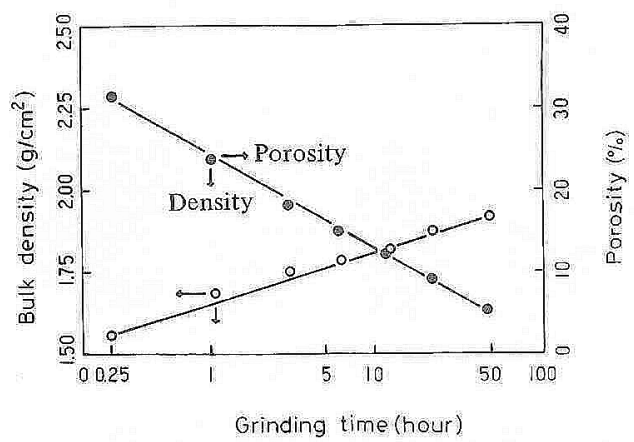

Fig. 6 Changes of bulk density and porosity of carbon solid heat-treated at $2700^{\circ} \mathrm{C}$ with grinding time.

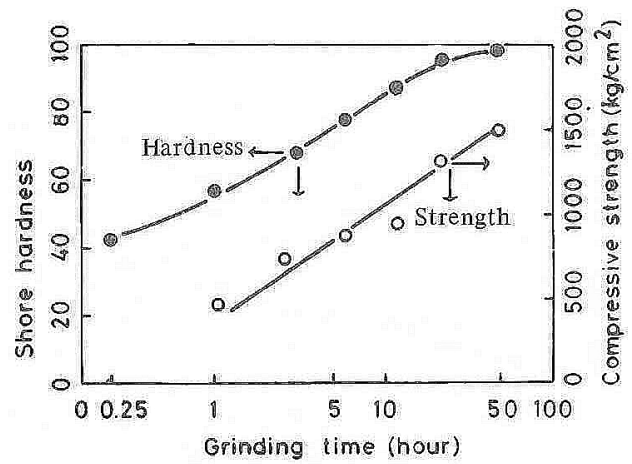

Fig. 7 Changes of shore hardness and compressive strength of carbon solid heat-treated at $2700^{\circ} \mathrm{C}$ with grinding time.

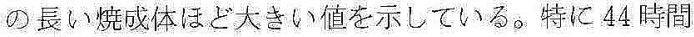
磨砕した原料により得られる焼成体は 100 に近い大さい ショアー便度老示す。

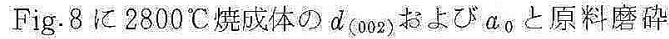

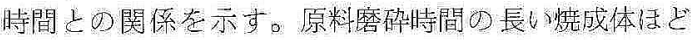

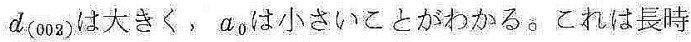

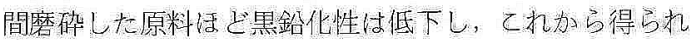
る焼成体は黑鉛化度加低いとと考示している。

Fig. 9 飞 44 時間磨砕した原料永ら得られた $2700^{\circ} \mathrm{C}$ 焼 成体の走査型電子顕微鏡写真定示与。図加ら和加るよう

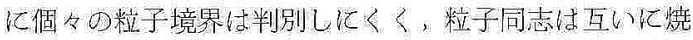

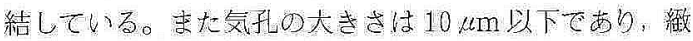
密柱組織者している。

以上のとと加ら，2700 Cまたは $2800 \mathrm{C}$ に処理した焼 成体は原料の磨砕時間が長いほど，高密度，高強度か心 高硬度であるとと，また墨鉛北度は低いととが判る。

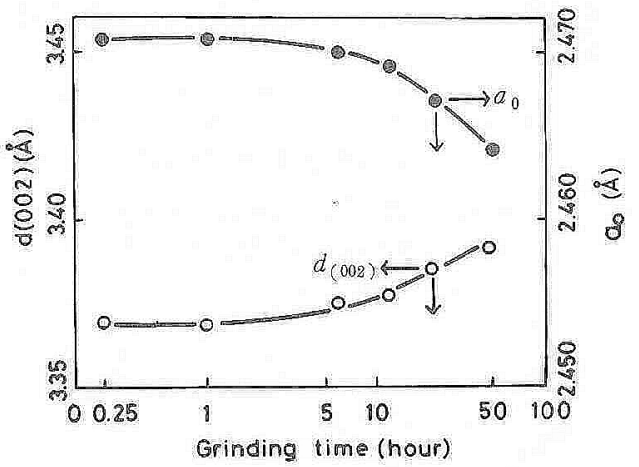

Fig. 8 Change of X-ray parameter of carbon solid heat-treated at $2800^{\circ} \mathrm{C}$ with grinding time.

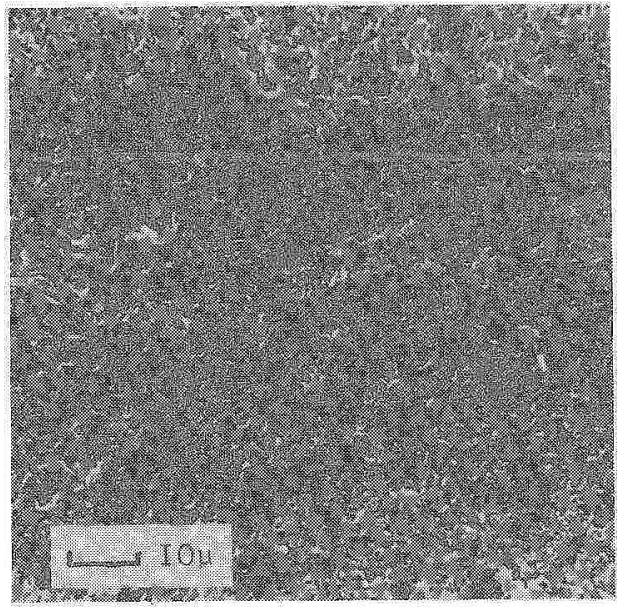

Fig. 9 Polished surface of carbon solid heattreated at $2700^{\circ} \mathrm{C}$ made from the powder ground for $44 \mathrm{hr}$. 


\section{4. 考察}

本実験により, 易黒鉛化性炭素である生石油コークス が長時間磨砕という強制手段によって, あはや易黒鉛化 ルートをたどりえない原料に変質されてしまったてとが 明らかになり，かつ，乙れを加圧成形し焼成した場合， 容易に隣接する粒子と焼結し, 全体として強固な焼成体 となることがわかった。

本実験で使用した原料は， $500^{\circ} \mathrm{C}$ 前後で製造された生 石油コークスである。筆者らは, 仮焼コークス粉末を原 料として同様な実験を試みたが，磨砕した仮焼コークス 粉末は角ばった形状を示し，乙れを成形，焼成しても強 固な焼成体は得られず，また黒鉛化にあ磨砕による顕著 な影響はみられなかった ${ }^{15)}$ 。このことは，原料の妈理温 度が高強度硬質炭素材を得るための重要な要素になって いるととを示している。

本実験で明らかになった如く，原料として生コークス を用いた場合，磨砕時間が長くなると原料粒子は次第に 球状化する。筆者らは，乙の球状化現象が主として剪断 応力によって粒子が塑性変形をおこしたためであり, こ の塑性変形のくりかえしがコークス粒子の諸性状を変化 させ, 結果的に磨砕した生コークスの難黒鉛化性および 焼成時の粒子間焼結を容易にさせた重要な因子になった と推定している。とのととから推察すれば, 高強度硬質 炭素材を得るには, 生コークスの如き, 比較的歪みやす く, かつ, 焼成時にふくれ上がりを生じない程度の揮発 分を含有する原料が適当であるといえる。

磨砕した生コークス粒子が難黒鉛化性を示すとと, ま た粒子間の焼結が容易であるととの理由については現在 明らかでなく，詳細な検討が必要であるが，難黒鉛化性 を示す原因の一つとして, 塑性変形により球状化した生 コークス粒子が，例えばサーマルブラックの如き内部構 造に変化したてと，また，大気中の酸素を吸着し，粒子 が酸素を含む分子集合体に変質したことなどが推察され る。また，粒子間の焼結を容易にさせた原因の一つとし て, 塑性変形にとあなう無定形構造部分の増加あるいは 低分子化が，焼成時の粒子間の物質移動を容易にさせた ことなどが挙げられる。

S. Mrozowski ${ }^{16,17)}$ は, 酸素が粒子表面に吸着された カーボン粉末はピッチバインダーなしで焼結するととを 見出している。本実験は, 空気雾囲気における磨砕であ るところから, 空気中の酸素が粒子表面に化学吸着し, これが焼成時に粒子表面を活性化したことも粒子間の焼 結をより容易にさせた一因として十分考えられる。

磨砕にと屯なうみかけ比重の増大は, 磨砕初期におけ る粒径の減少および塑性変形によって粒子中の閉鎖気孔
が押しつぶされたととによるあのと考えられる。また， 揮発分の増加は, 塑性変形によって分子間結合が切断さ れて低分子が開放されたてとによるものと考えられる。 さらに本実験で明らかになった事実は, 燃焼する際, 昇温速度が遅いと焼成体がクラックの発生, あるいは, 崩壊状態を示すととである。この現象は従来の常識と反 することであるが，乙れと類似の現象は山田ら ${ }^{12)}$ のメン カーボン・マイクロビーズを原料とする炭素材の製造に おいて観察されている。その原因については, 焼成中の 揮発㕣の脱離と粒子間焼結との速度あるいは時期の差が 重要な因子になっていると推察されるが，その詳細につ いては現在明らかでない。

本報告で示したように，十分磨砕した生コークス原料 を用いると, 成形と焼成するのみで高強度の炭素材が得 られる事実は, 本製造法が従来の炭素材料製造の場合に 必要なピッチ混練, 炭化および黒鉛化という複雑な工程 を簡素化できる長所をもっていることを示している。ま た従来法により高密度製品を得るためには，ピッチ含浸 と焼成を数回反復させることが必要とされているのに対 して, 本実験に扣いては高密度炭素製品(かさ密度約 1.9 $\mathrm{g} / \mathrm{cm}^{3}$, 原料磨砕 44 時間)が一回の焼成工程で得られる。 この事実は, 本方法が高密度炭素製品の新しい製造法の 一つとして発展しうることを示しているといえる。

\section{5. まと め}

約 $500{ }^{\circ} \mathrm{C}$ で製造された石油コークスを磨砕し, 粘結材 を用いることなくこれを成形したのち，焼成することに より炭素材の製造を試みた。その結果，原料コークスを 磨砕することによって, 得られる炭素材の緻密化は著し く促進され, 本実験の場合, 約 20 時間以上の磨砕原料 加高密度, 高強度汃高硬度の炭素材が得られること がわかった。すなわち，

1. 磨砕によって生コークスのみかけ比重と揮発分量 は増大した。また(002)X線回折図形はよりブロードと なり，汃低角側へ移行した。

2. 磨砕した生コークスを成形, 焼成することにより, 粘結材を用いることなく炭素材を製造できることがわか った。

3. $2700^{\circ} \mathrm{C}$ または $2800^{\circ} \mathrm{C}$ に処理した場合, 原料の磨 砕時間が長い炭素材ほど, かさ密度, 強度および硬度は 高い值を示した。また，炭素材の黒鉛化度は原料の磨砕 時間が長いほど低下した。

4. とくに, 約 20 時間以上磨砕した原料を使用した 場合, 高密度 (かさ密度, 約 1.9 ), 高強度 (圧縮強度 1500 $\mathrm{kg} / \mathrm{cm}^{2}$ ), 高硬度 (ショアー硬度約 100) の低黒鉛化度 $\left(d_{(002)}=3.40 \AA\right)$ の炭素材が得られた。 
終わりに本研究について種々御討論いただいた九州工 業技術試験所, 山田泰弘主任研究官に謝意を表します。

\section{文献}

1) W. C. Chard and D. E. Niesz, Abstract for the 11 th Carbon Conf. 1973.

2）稲垣，中，粉体扰よび粉体冶金， $\mathbf{1 9 7 5} ， 22 ， 87$.

3）稲垣, 三輪, 炭素, 1976, 〔No.85〕, 69.

4) 小林, 松下, 小川, 本田, 炭素, 1975, 〔No. 82], 118.

5）松下, 萩尾, 小林, 本田, 炭素, 1976, 〔No. 86], 112 .

6）萩尾, 松下, 小林, 本田, 炭素, 1976, 〔No. 89], 60 .

7）大谷, 久保田, 大谷, 小板橋, 炭素, 1968, 〔No. 52], 13.
8）大谷, 大谷, 深堀, 工化誌, 72,〔1〕,317, (1969)

9）大谷, 大谷, 中川, 深堀, 工化誌, 72,〔1〕, 323, (1969)

10）大谷, 大谷, 長島, 工化誌, 73,〔10〕, 2095, (1970)

11）大谷, 大谷, 岡田, 日化誌, 〔No.12〕, 2318, (1974)

12）山田, 柴田, 本田, 大井, 炭素, 1976, No. 88], 2 .

13）向原, 鈴木, 窝業協会誌, 84,〔11〕, 525, (1976)

14）久保, メカノケミストリー概論, 東京化学同人, 1971.

15）小川, 小林, 未発表

16) S. Mrozowski, US Patent, 2682686, 1954

17) S. Mrozowski, Proc. 3rd Conf. on Carbon, P 495, Pergamon Press (1957)

\section{記}

\section{第 12 回 ブラシ懇談会}

昭和 52 年 2 月 10 日 (木) $13.00 \sim 16.00$ 亿第 12 回の「電 気機械用ブラシに関する懇談会」が神田学士会館におい て開催された。30名が参加し，下記の提出資料を中心之 して活発に意見の交換が行われた。

No. 12-1 直流機の整流とブラシ接触特性

（東芝）森田 登

№. 12-2シリコンガスのブラシ摩耗に与える影響

（富士）久野高司ほか

№. 12-3 整流火花による負ブラシの損傷について

（日本工大）武政隆一ほ加

№. 12-4 脈動電圧印加時の整流火花波形について

（日本工大）武政隆一ほか

\section{第 13 回 ブラシ懇談会}

昭和 52 年 6 月 17 日(金) $13.00 \sim 16.00$ 亿第 13 回の「電 気機械用ブラシに関する懇談会」が神田学士会館におい て開催された。31名が参加し，下記の提出資料を中心之 して活発に意見の交換が行われた。

No. 13-1 脈動電源駆動直流機の無火花帯の解析
No. 13-2 過渡時における直流直巻電動機の整流火花 （法政大）山村竜男ほ力

N0. 13-3 CM系金属黒鉛質ブラシの調査(1)

（富士カーボン製造）熊谷正博ほか

No. 13-4 各社カタログ表示項目

（富士カーボン工業）長野美雄

No. 13-5 ブラシの摩耗に対する振動の影響について （日立化成）宇津 威ほか

№. 13-6 ブラシの厚さと摺動特性との関係について （日本工大）武政隆一ほか

\section{第 14 回 ブラシ懇談会}

昭和 52 年 10 月 14 日 (金) 13.00 15.30 亿第 14 回の 「電気機械用ブラシに関する懇談会」が神田学士会館に おいて開催された。25名が参加し，下記の提出資料を中 心として活発に意見の交換が行われた。

NN. 14-1 高温領域における無火花帯の変動

（日本工大）武政隆一ほか

№. 14-2 ブラシ材料の耐アーク性について

（日本工大）武政隆一ほか

（東芝）森田 登 